\title{
DOSE-EFFECT RELATIONSHIP ON ANTI-INFLAMMATORY ACTIVITY ON LPS INDUCED RAW 264.7 CELLS AND ANTIOXIDANT ACTIVITY OF RUTIN IN VITRO
}

\author{
CHUNLIAN TIAN ${ }^{1,2}$, YURU GUO, YU CHANG, JIHANG ZHAO, CANCAN CUI \\ and MINGCHUN LIU*
}

${ }^{1}$ College of Animal Science and Veterinary Medicine, Shenyang Agricultural University, No 120 Dongling Road Shenhe Dist. 110866, Shenyang Liaoning Prov., People's Republic of China

${ }^{2}$ Key Laboratory of Molecular Pharmacology and Drug Evaluation (Yantai University), Ministry of Education", Yantai University, 264005, Yantai Shangdong Prov., People's Republic of China

\begin{abstract}
Rutin, as a common flavonol glycoside, exists abundantly in many plants and exhibits various nutritional and pharmacological function. The current study focused on the dose-effect relationship of rutin on the anti-inflammatory and antioxidant activities in vitro against LPS-stimulated RAW 264.7 cells and free radicals or ferric-ion. This study evaluated the anti-inflammatory activity by observation cell morphological and determination of the content of NO, TNF- $\alpha$, IL-1 $\beta$, and IL-6, and the phagocytic activity in LPS induced RAW 264.7 cells; and revealed the antioxidant activities via assay of DPPH radical scavenging capacity, ABTS radical scavenging capacity, and reducing power. The study indicated that 5, 10, 20, 50 and $100 \mu \mathrm{M}$ of rutin all exhibited a better anti-inflammatory activity, especially 50 and $100 \mu \mathrm{M}$. Meanwhile, it exerted stronger antioxidant activities than $\mathrm{BHT}$, and equivalent to $\mathrm{VC}$ at the same concentration. Combined, the results suggested that rutin will be a potential and important adjuvant in the treatment of inflammatory diseases and oxidative stress.
\end{abstract}

Keywords: rutin, lipopolysaccharide, dose-effect relationship, anti-inflammatory, antioxidant

Inflammation is associated with many diseases, including bronchitis, pneumonia, gastritis, nephritis, and rheumatism (1-3). In addition, oxidative damage, as an important factor for aging and oxidative stress diseases, is closely related to excessive free radical $(4,5)$ and often occurs in cardiovascular, cancer and inflammation diseases $(6,7)$. Therefore, the treatment of inflammation and the elimination of harmful free radicals will be a more effective way of preventing all kinds of diseases and keeping a balance of the internal environment. Macrophages, which are a kind of cells regulating inflammatory responses and production of inflammatory mediators, can regulate the immune system by secretion of various cytokines or release of lysosomal enzymes $(8,9)$. RAW264.7 cell lines were mouse mononuclear macrophage leukemia cells, which is widely used to evaluate the anti-inflammatory effect of mononuclear macrophages in vitro (10, 11). In addition, it is very necessary for research and development of natural, green, and health medicines in order to avoid the adverse reactions of steroidal, non-steroidal anti-inflammatory drugs (12-15) and synthetic antioxidants $(16,17)$. As a flavonol glycoside, rutin widely exists in vegetables, fruits and other plants, including buckwheat, asparagus, eggplant, tomato, green pepper, tea, rue leaf, tobacco, blackberry, grape, etc, and exhibits nutritional (18) and pharmacological function (19-21), such as antiinflammatory (22-25), antioxidant $(6,7,25,26)$, prevention of neurodegenerative disorders (27), antiglycation (28), improving kidney and heart structure and function (29).

Yang (30) analyzed the antioxidant activity of rutin by assay of total antioxidant ability, reducing power, lipid peroxidation, scavenging activity of hydroxyl, superoxide, and 1,1-diphenyl-2-picrylhydrazyl (DPPH) radicals, and revealed that rutin had a better function on scavenging radicals and inhibition of lipid peroxidation. Another reported study suggested that rutin can prevent cisplatininduced nephrotoxicity by decreasing of the oxidative stress, repairing the histopathological changes and inhibiting the activation of ROS/JNK/TNF/P38

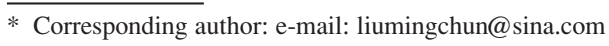


MAPK signaling pathways (31). In addition, rutin exhibited stronger protection from physiology, biochemistry and immunology against methotrexateinduced intestinal toxicity in a dose-dependent manner, which is on account of the anti-inflammatory and antioxidant effects of rutin, including scavenging activity of free radical, immunoregulatory and dual inhibitory the metabolism of arachidonic acid (32).

However, no systematic study has been performed about the dose-effect relationship of rutin on the anti-inflammatory and antioxidant activities in vitro. Therefore, the major objectives of this paper were to investigate the dose-effect relationship of rutin on the anti-inflammatory activity with the model of LPS induced RAW 264.7 cells and to evaluate the antioxidant activities via assay of the scavenging capacity of DPPH, ABTS radicals, and reducing power.

\section{MATERIALS AND METHODS}

Cells

RAW 264.7 murine macrophage cells were purchased from Shanghai cell line bank of Chinese Academy of Sciences (Shanghai, China) and cultured in RPMI 1640 medium containing 10\% fetal bovine serum, $100 \mathrm{U} / \mathrm{mL}$ penicillin and streptomycin mixture with supplement $5 \% \mathrm{CO}_{2}$ at $37^{\circ} \mathrm{C}$.

\section{Chemicals and reagents}

2, 2'-azino-bis(3-ethylbenzothiazoline-6-sulfonic acid diammonium salt) (ABTS), DPPH and 2, 4,6-tri(2-pyridyl)-s-triazine (TPTZ) were purchased from Sigma-Aldrich Chemie (Steinheim, Germany). Interleukin-1 $\beta$ (IL-1 $\beta$ ), IL-6 and TNF- $\alpha$ Elisa kits were obtained from eBioscience (Science Center Drive San Diego, CA, USA). Escherichia coli Lipopolysaccharide (LPS), dimethyl sulfoxide (DMSO), 3-(4,5-dimethylthiazol -2-yl)-2,5-diphenyltetrazolium bromide (MTT), butylated hydroxytoluene (BHT) and ascorbic acid were purchased from Sigma-Aldrich (St. Louis, MO, USA), and rutin was purchased from Dalian Meilun Biotechnology co., LTD (Dalian, China). Other chemicals and reagents were all analytically pure and obtained from Sinopharm Chemical Reagent Co., Ltd (Shanghai, China).

\section{Experimental protocol}

Cells were randomly divided into eight groups as follows: control group, LPS group (1 $\mu \mathrm{mol} / \mathrm{L})$, LPS $+2 \mu \mathrm{mol} / \mathrm{L}$ of dexamethasone (Dex) group, $\mathrm{LPS}+5,10,20,50$ and $100 \mu \mathrm{mol} / \mathrm{L}$ of rutin groups.

\section{Determination of anti-inflammatory activity Cell viability}

The cytotoxicity of rutin against RAW 264.7 cells was evaluated using the MTT assay according to the method described by Kim (10) and Tian (11). Cells were cultured with concentration of $1 \times 10^{5} /$ well and grouped into eight groups on the basis of the experimental protocol. Then, $50 \mu \mathrm{L}$ of $1 \mu \mathrm{mol} / \mathrm{L}$ LPS was added to all groups except the control group with 50 $\mu \mathrm{L}$ of culture medium. $20 \mu \mathrm{L}$ of $5 \mathrm{mg} / \mathrm{mL}$ MTT reagent was mixed with the supernatant after incubated for $18 \mathrm{~h}$, and cultured continually for $4 \mathrm{~h}$.

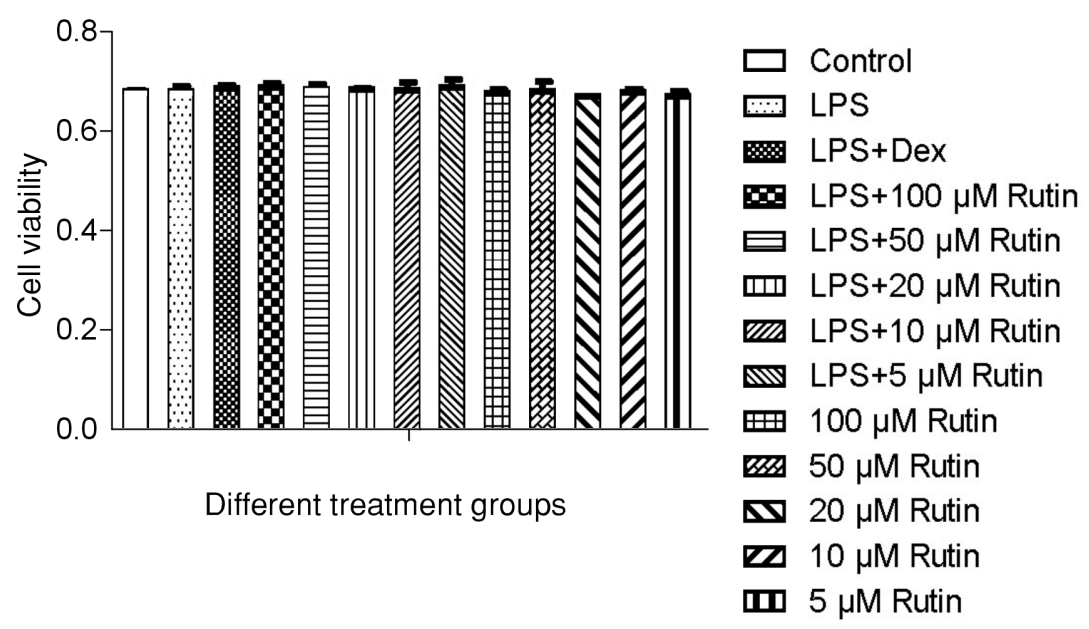

Figure 1. Effect of rutin on the viability of RAW 264.7 cells. Data are presented as means \pm SD of three independent experiments. p values $<0.05$ were regarded as statistically significant and $p$ values $<0.01$ as very significance 


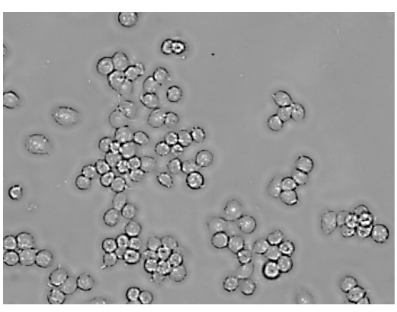

A

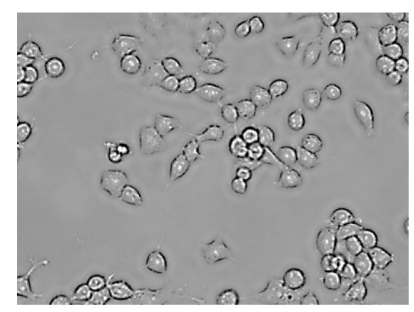

D

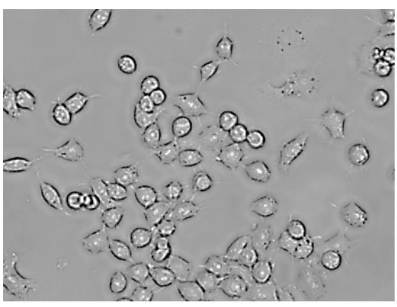

G

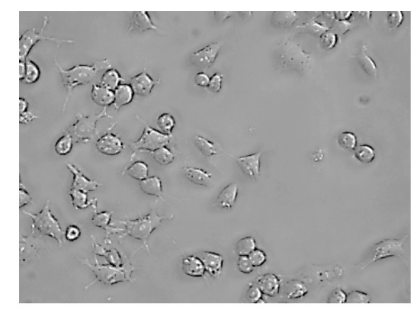

B

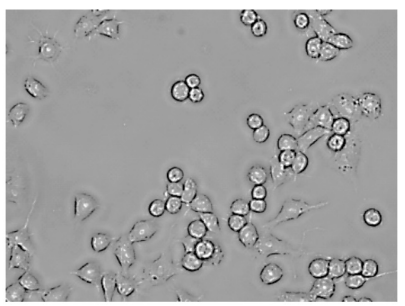

E



$\mathrm{H}$

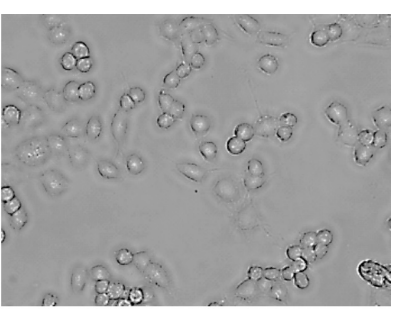

C

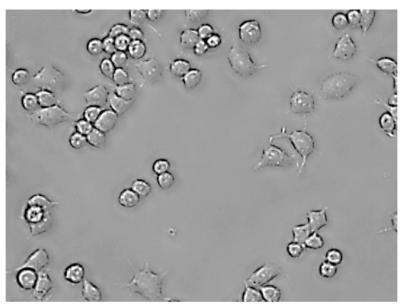

$\mathrm{F}$

Figure 2. The optical microscopic morphology of RAW 264.7 cells in different treatment groups $(40 \times)$
A: Control
B: LPS
C: $\mathrm{LPS}+2 \mu \mathrm{M}$ Dex
D: LPS + $100 \mu \mathrm{M}$ Rutin
E: LPS + $50 \mu \mathrm{M}$ Rutin
F: LPS $+20 \mu M$ Rutin
G: LPS + 10uM Rutin
H: LPS + $5 \mu$ M Rutin

Then, $150 \mu \mathrm{L}$ of dimethyl sulfoxide was supplemented follow by discarding the supernatant and shaken gently and then measured by microplate reader detection at $490 \mathrm{~nm}$.

\section{Cell morphology}

Cell morphology is a manifestation of the state of cell growth. Cells were incubated for $18 \mathrm{~h}$ and their morphology was observed by microscope.

\subsubsection{Measurement of NO content}

The content of NO was analyzed according to the Griess reagent method reported by Tian (11). The diluents of standard sodium nitrite and the culture supernatant were mixed respectively with isovolumetric of reactive solvent, which was consisted with $1.0 \mathrm{~g}$ of anhydrous sulfanilic acid, $6 \mathrm{~mL}$ of $85 \%$ phosphoric acid and $94 \mathrm{~mL}$ of deionized water, and incubated at $37^{\circ} \mathrm{C}$ for $10 \mathrm{~min}$. Then, the mixture was added with $0.1 \%$ n-naphthylethylenediamine solution and incubated for $10 \mathrm{~min}$. The absorbance was measured at $540 \mathrm{~nm}$ and the concentration of $\mathrm{NO}$ was calculated from an established standard curve of sodium nitrite.

\section{Measurement of cytokines}

The levels of TNF- $\alpha$, IL- $1 \beta$ and IL- 6 in cell supernatant were measured by ELISA kits according to the manufacturer's instruction.

\section{Measurement of phagocytic activity}

Phagocytic activity of RAW 264.7 cells was evaluated by the scavenging ability of toluylene red reagent. Cells were grouped into eight groups under the density of $1 \times 10^{5}$ cells/well and incubated with different concentrations of rutin or Dex, except control and LPS groups, and then reacted with $100 \mu \mathrm{L}$ of $100 \mathrm{mg} / \mathrm{mL}$ neutral red solution for $30 \mathrm{~min}$ after 
incubated for $18 \mathrm{~h}$. After cells were sealed with $100 \mu \mathrm{L}$ of cell lysis solution (ethanol : ice acetic acid $=1: 1, \mathrm{v}: \mathrm{v}$ ) at room temperature for overnight, and then the absorbance was measured with enzyme marker at $540 \mathrm{~nm}$.

\section{Determination of antioxidant activities ABTS radical scavenging activity assay}

ABTS radical scavenging activity of rutin was measured with the method of Tian (11). ABTS radical cation $\left(\mathrm{ABTS}^{+}{ }^{+}\right)$was prepared with the mixture of $7 \mathrm{mmol} / \mathrm{L}$ ABTS and $2.45 \mathrm{mmol} / \mathrm{L}$ potassium persulfate at room temperature in the dark for 12-16 $\mathrm{h}$, and then ABTS solution was diluted with PBS to obtain an absorbance of $0.700 \pm 0.02$ at $734 \mathrm{~nm}$. Different concentration of rutin was mixed with ABTS working solution and incubated for $30 \mathrm{~min}$ and the absorbance was measured at $734 \mathrm{~nm}$. The scavenging ability was calculated by the following equation: scavenging rate $(\%)=\left[\left(\mathrm{A}_{0}-\mathrm{A}_{1}\right) / \mathrm{A}_{0}\right] \times 100 \%$, where $A_{0}$ and $A_{1}$ were the absorbances of ABTS solution and ABTS solution with sample solution at different concentration, respectively. The antioxidant activity was expressed by $\mathrm{IC}_{50}(\mu \mathrm{g} / \mathrm{mM})$, which is the concentration of rutin for inhibition of $50 \%$ free radicals.

\section{DPPH radical scavenging activity assay}

Scavenging DPPH radical activity of rutin was measured with the method described by Tian (11). $0.1 \mathrm{~mL}$ of different concentration of rutin was mixed with $0.9 \mathrm{~mL}$ of $0.1 \mathrm{mmol} / \mathrm{L} \mathrm{DPPH} \cdot$ radicals ethanol solution and incubated for $30 \mathrm{~min}$ at $37^{\circ} \mathrm{C}$ in the dark. The absorbance of the resulting solution was recorded at $517 \mathrm{~nm}$ and the values of $\mathrm{IC}_{50}$ were determined according to the method reported above.

\section{Ferric-ion reducing antioxidant power assay}

According to the method of Tian (11), ferricion reducing antioxidant power (FRAP) of rutin was measured. An aliquot of different concentration of rutin was reacted with FRAP reagent and incubated darkly for $30 \mathrm{~min}$ at $37^{\circ} \mathrm{C}$. The absorbance was measured at $593 \mathrm{~nm}$ and the values were expressed as $\mathrm{mmol} \mathrm{Fe}^{2+}$ per $\mu \mathrm{g} / \mathrm{mL}$ of rutin.

\section{Statistical analysis}

The statistical analysis was performed by SPSS 17.0 (SPSS Inc., Chicago, IL). Experiment values were means of three replicate samples $(n=3)$ and expressed as means \pm standard deviation. In all statistical analyses, $\mathrm{p}$ values $<0.05$ were regarded as statistically significant and $\mathrm{p}$ values $<0.01$ were very significant.

\section{RESULTS AND DISCUSSION}

\section{Anti-inflammatory activity analysis Effect of rutin on the cell viability}

The examination of cytotoxicity of rutin in RAW 264.7 macrophages by MTT assay indicated that rutin even at the concentration of $40 \mu \mathrm{M}$, did not decrease cell viability in RAW 264.7 cells (35). As shown in Figure 1, cell viability was not significantly ( $p>0.05)$ affected by LPS, Dex and rutin in the experimental concentration range from 5 to $100 \mu \mathrm{M}$. The results revealed that there was no poisonous effect on the RAW 264.7 cells for the rutin, Dex and LPS under the experimental concentration and the inhibition of LPS-induced inflammation by rutin was not the result of their cytotoxicity on cells.

\section{Effect of rutin on cell morphology}

Figure 2 described the optical microscopic morphology $(40 \times)$ of RAW 264.7 cells in different treatment groups. As shown in Figure 2A for the control group, the morphology of RAW 264.7 cells was normal with round or elliptic shape and the cells were closely exposed to cluster growth. However, the cells were in a differentiated state with a larger branch, fast growth and expansion, significant increasing of spacing and distinct antennae after induced by LPS (Fig. 2B). In addition, the branching cells were significantly reduced in Dex and rutin groups, and most of the cells were round or elliptic, and returning to normal form (Fig. $2 \mathrm{C}$ to $2 \mathrm{H}$ ). These results indicated that $1 \mu \mathrm{mol} / \mathrm{L}$ of LPS can successfully induce inflammation and morphology differentiation for RAW 264.7 cells and the treatment of different concentration of rutin can effectively inhibit cell differentiation and alleviate inflammatory reaction.

\section{Effect of rutin on the content of $\mathrm{NO}$}

As an important inflammatory medium, NO plays an important role in the occurrence and development of inflammation. When RAW 264.7 macrophages were treated with $5,10,20,40 \mu \mathrm{M}$ of rutin together with LPS (100 ng/mL) for $24 \mathrm{~h}$, the significant concentration-dependent inhibition of nitrite production was detected in the presence of rutin (35). The inhibitory effect of $12.21,24.42,48.84$ $\mu \mathrm{g} / \mathrm{mL}$ of rutin on NO production increased with dose and reduced nitrite accumulation with the highest reduction being approximately 40-50\% (36). According to the results in Figure 3, the content of NO was improved very significantly $(\mathrm{p}<0.01)$ in LPS model group comparing to the control group; and decreased very significantly $(\mathrm{p}<0.01)$ with a 
dose-dependent manner in the experimental groups pretreated by $5,10,20,50$ and $100 \mu \mathrm{M}$ of rutin compared with the LPS model group. This results indicated that LPS-induced NO production was inhibited by a certain concentration of rutin, and the inhibitory effect of $100 \mu \mathrm{M}$ of rutin was stronger than Dex $(\mathrm{p}<0.01)$, and $5-100 \mu \mathrm{M}$ of rutin was equivalent to Dex $(\mathrm{p}>0.05)$, which suggests that low concentration of rutin can play the same role as Dex in reducing the content of inflammatory medium NO in clinical practice. Moreover, it will be paid more attention to rutin due to the small toxic and side effects.

\section{Effect of rutin on cytokines secretion}

As described in the research of Saraphanchotiwitthaya et al. (36), 12.21, 24.42, $48.84 \mu \mathrm{g} / \mathrm{mL}$ of rutin can substantially inhibit the increasing of IL-1 $\beta$ levels, which was significantly secreted by stimulation of RAW 264.7 cells with LPS $(5 \mu \mathrm{g} / \mathrm{mL})$ approximately 3 -folds over basal secretion values. However, at the tested concentrations, rutin did not have any effect on TNF- $\alpha$ production. The inhibition of rutin on TNF- $\alpha$, IL-1 $\beta$ and IL-6, which were produced by activated macrophages, were shown in Figure 4 to 6 . The results revealed that the production of TNF- $\alpha$, IL-1 $\beta$ and IL- 6 was very significant increased $(\mathrm{p}<0.01)$ in LPS induced RAW 264.7 cells, which were very significantly reversed $(\mathrm{p}<$ 0.01 ) by treatment of 50 and $100 \mu \mathrm{M}$ rutin and Dex. In addition, the content of IL- 6 was decreased significantly $(\mathrm{p}<0.01)$ by low concentration of rutin, including 5, 10 and $20 \mu \mathrm{M}$. However, there was no very significant difference $(\mathrm{p}>0.01)$ between the inhibiting effect for low concentration of rutin and the content of TNF- $\alpha$ and IL- $1 \beta$. It can be seen that there was very significant or significant difference between 5, 10, 20 and $50 \mu \mathrm{M}$ of rutin and Dex $(\mathrm{p}<$ 0.01 or $p<0.05$ ) on the secretion of TNF- $\alpha$, IL- $1 \beta$ and IL-6, and no significant difference between 100 $\mu \mathrm{M}$ of rutin and Dex $(\mathrm{p}>0.05)$ on the content of IL$1 \beta$ and IL-6 from the comparison of differences between different treatment groups. The research suggests that $100 \mu \mathrm{M}$ of rutin can alleviate LPSinduced inflammatory reaction via down-regulation of pro-inflammatory cytokines IL-1 $\beta$ and IL-6 expression, directly to suppress the occurrence and development of inflammation, which means that $100 \mu \mathrm{M}$ or higher of rutin will be a candidate antiinflammatory drug for research and development in clinical inflammatory diseases.

\section{Effect of rutin on phagocytic activity}

For evaluation the immunoactivity of polysaccharides of $L$. barbarum (LBP), the phagocytic activity was evaluated by uptake of toluylene red in murine macrophage RAW264.7 cells and the results indicated that the phagocytic activity of macrophages cells showed a notable increase with the increasing of the LBP concentration from 15.6 to $500 \mu \mathrm{g} / \mathrm{mL}$ after treatment with LBPs (37). Figure 7 described the results of phagocytic activity of RAW 264.7 cells after pretreated with different concentration of rutin, Dex and LPS. The results illustrated that the phagocytosis of RAW 264.7 cells was very significant increased $(p<0.01)$ after LPS induced comparing to the control group, which was indicating that the inflammatory experiment model was successfully established. Compared with LPS model group, 20, 50 and $100 \mu \mathrm{M}$ of rutin and Dex can reduce the phagocytic activity very significantly $(\mathrm{p}<0.01)$ in a dose-dependent manner, and signifi-

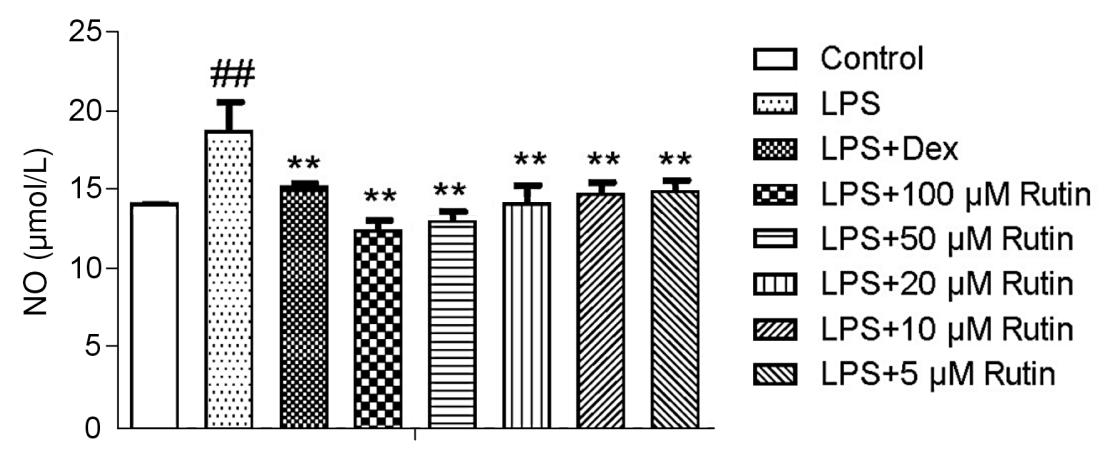

Different treatment groups

Figure 3. Effects of different concentrations of rutin on LPS induced NO production in RAW 264.7 cells. Values represent the mean \pm SD of the three independent experiments ( ${ }^{*}$ compared with the control, $*$ compared with LPS, $* / * \mathrm{p}<0.05, * * /{ }^{*} \mathrm{p}<0.01$ ) 


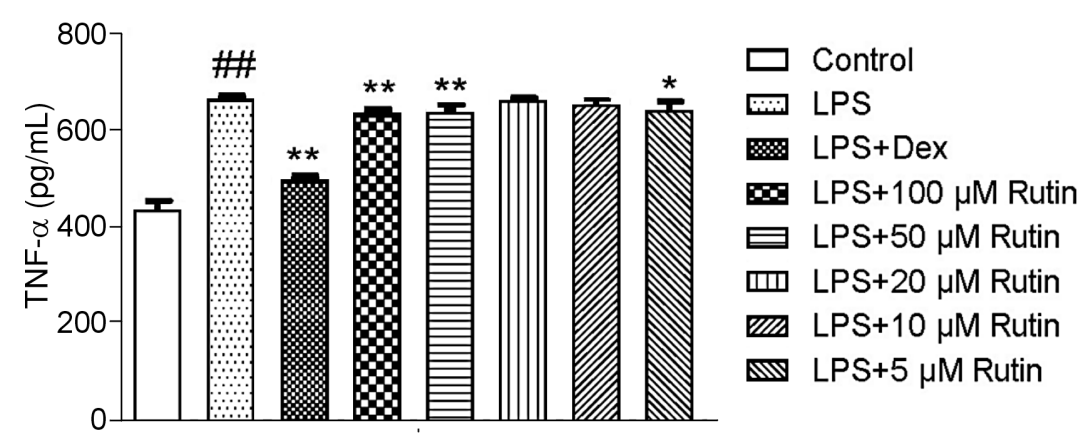

Different treatment groups

Figure 4. Effects of different concentrations of rutin on LPS induced TNF-á production in RAW 264.7 cells. Values represent the mean \pm $\mathrm{SD}$ of the three independent experiments ("compared with the control, *compared with LPS, */"p $<0.05, * * / * \mathrm{p}<0.01$ )

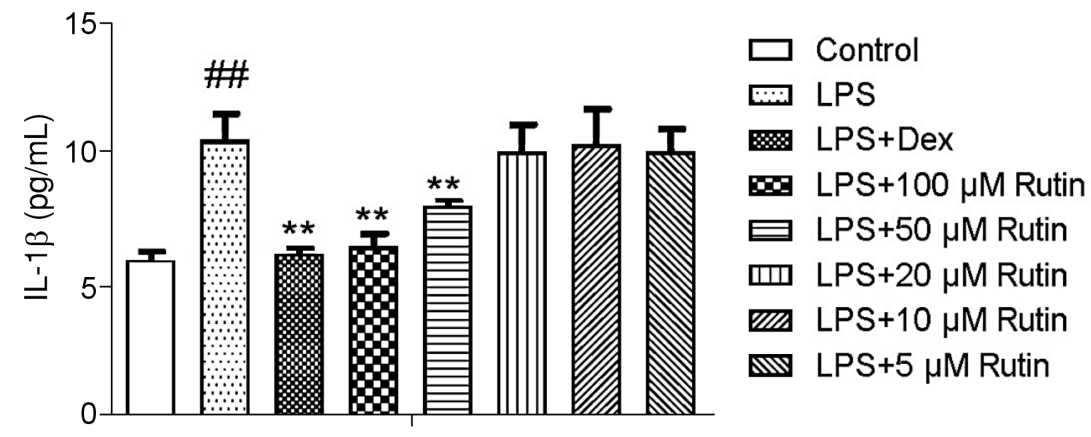

Different treatment groups

Figure 5. Effects of different concentrations of rutin on LPS induced IL-1â production in RAW 264.7 cells. Values represent the mean \pm $\mathrm{SD}$ of the three independent experiments ("compared with the control, *compared with LPS, */" $\mathrm{p}<0.05, * * /{ }^{*} \mathrm{p}<0.01$ )

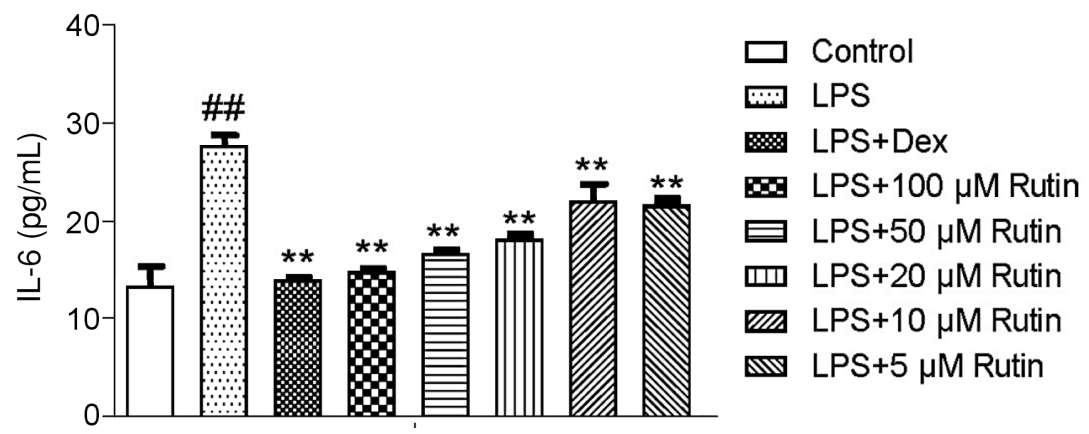

Different treatment groups

Figure 6. Effects of different concentrations of rutin on LPS induced IL-6 production in RAW 264.7 cells. Values represent the mean \pm $\mathrm{SD}$ of the three independent experiments ( ${ }^{*}$ compared with the control, *compared with LPS, */ $\mathrm{p}<0.05, * * /{ }^{*} \mathrm{p}<0.01$ ) 
cantly $(\mathrm{p}<0.05)$ for $10 \mu \mathrm{M}$ of rutin. However, there was no significant difference $(\mathrm{p}>0.05)$ between the treatment group of $5 \mu \mathrm{M}$ of rutin and LPS model group, which was indicating that $5 \mu \mathrm{M}$ of rutin had no perfect anti-inflammatory effect. From the results of statistical analysis between any two groups, there was very significant or significant difference between $5 \mu \mathrm{M}$ or $10 \mu \mathrm{M}$ of rutin and Dex $(\mathrm{p}<0.01$ or $\mathrm{p}<0.05)$, but no significant for 20,50 and $100 \mu \mathrm{M}$ of rutin $(\mathrm{p}>0.05)$, which was implying that $20 \mu \mathrm{M}$ or more of rutin can exhibit the same antiinflammatory effect as Dex. What's even more remarkable is that rutin has a better anti-inflammatory effect but also has a smaller adverse reaction.

It was demonstrated that rutin can effectively attenuate the inflammatory response by improving cell morphology in LPS-induced RAW264.7 cells. The mechanisms underlying this protective effect include a reduction in the content of $\mathrm{NO}$, inhibiting cytokines secretion and decreasing phagocytic activity.

\section{Antioxidant activity analysis \\ Antioxidant activity of rutin against ABTS, DPPH radicals and FRAP}

The ABTS and DPPH radicals scavenging activities of rutin, BHT and VC were demonstrated with the $\mathrm{IC}_{50 \mathrm{ABTS}}$ and $\mathrm{IC}_{50 \mathrm{DPPH}}$ values, and the reducing capacity was evaluated with the same concentration of ferrous ions. The $\mathrm{IC}_{50}$ value is inversely proportional to the antioxidant capacity, while FRAP is directly proportional to it. The antioxidant activity assay results of rutin, BHT and VC were described in Table 1 and Figures 8 to 12 .

When assay of the actual Trolox equivalent antioxidant capacity of antioxidants, i.e. the total antioxidant capacity, rutin, as an analytic target, was tested with the concentration of 0.305 to 0.916 $\mu \mathrm{g} / \mathrm{mL}$ for optimization the concentration range of ABTS working solution. However, $\mathrm{IC}_{50 \mathrm{ABTS}}$ of rutin was not calculated and fitted (33). As shown in Table $1, \mathrm{IC}_{50 \text { ABTS }}$ of rutin was the lowest with 0.85 $\mu \mathrm{g} / \mathrm{mL}$, followed by $\mathrm{VC}$ with $2.36 \mu \mathrm{g} / \mathrm{mL}$, and BHT with the highest value of $25.69 \mu \mathrm{g} / \mathrm{mL}$, namely, rutin exhibited stronger ABTS radicals scavenging activity than VC and BHT.

There was a slightly different for ABTS radicals scavenging activity, and $\mathrm{VC}$ was a better antioxidant against DPPH radicals with the $\mathrm{IC}_{50 \mathrm{DPPH}}$ $3.18 \mu \mathrm{g} / \mathrm{mL}$, followed by rutin with $\mathrm{IC}_{50 \mathrm{DPPH}} 5.18$ $\mu \mathrm{g} / \mathrm{mL}$, and finally BHT with $\mathrm{IC}_{50 \text { DPPH }} 7.77 \mu \mathrm{g} / \mathrm{mL}$. Comparing to BHT, rutin and VC both displayed more perfect scavenging abilities for DPPH free rad-

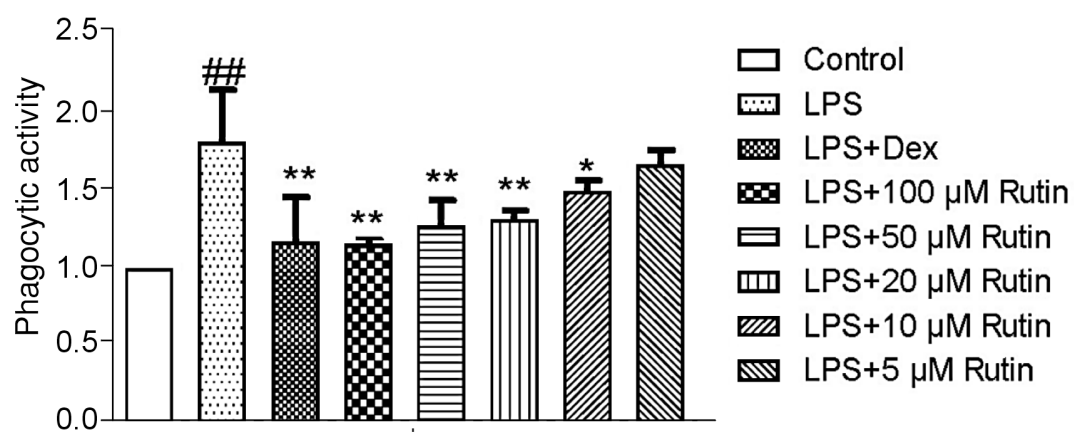

\section{Different treatment groups}

Figure 7. Effects of different concentrations of rutin on LPS induced phagocytic activity in RAW 264.7 cells. Values represent the mean $\pm \mathrm{SD}$ of the three independent experiments ("compared with the control, *compared with LPS, */ $\mathrm{p}<0.05, * * /{ }^{*} \mathrm{p}<0.01$ )

Table 1. $\mathrm{IC}_{50}$ values for evaluated antioxidant assays and reducing power of rutin, BHT and VC.

\begin{tabular}{|c|c|c|c|}
\hline Sample & $\begin{array}{c}\mathrm{IC}_{50} \text { ABTS } \\
(\mu \mathrm{g} / \mathrm{mL})\end{array}$ & $\begin{array}{c}\mathrm{IC}_{50} \mathrm{DPPH} \\
(\mu \mathrm{g} / \mathrm{mL})\end{array}$ & $\begin{array}{c}\text { FRAP } \\
\left(\mathrm{mmol} \mathrm{Fe}^{2+} / \mu \mathrm{g} / \mathrm{mL}\right)\end{array}$ \\
\hline Rutin & 0.85 & 5.18 & 0.028 \\
\hline BHT & 25.69 & 7.77 & 0.021 \\
\hline VC & 2.36 & 3.18 & 0.026 \\
\hline
\end{tabular}

$\mathrm{IC}_{50}, 50 \%$ of inhibition concentration 


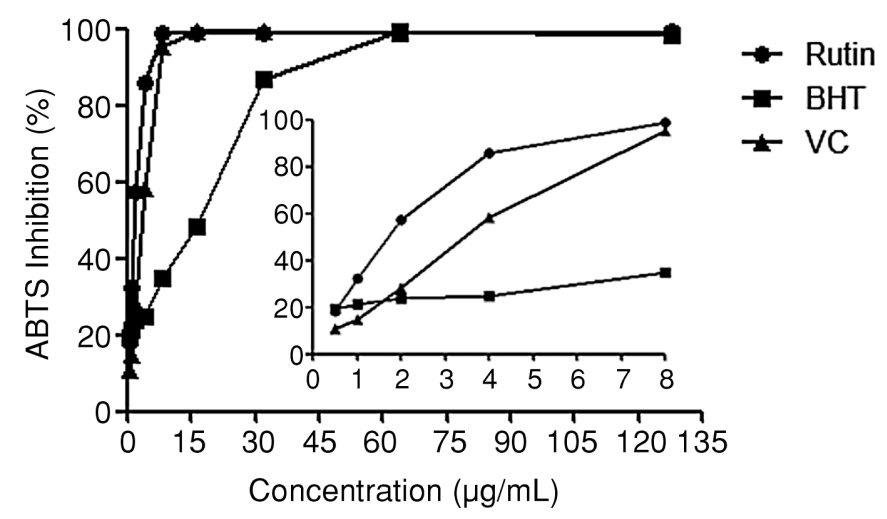

Figure 8. The scavenging activity of different concentrations of rutin, BHT and VC on ABTS radical. Values represent the mean \pm SD of the three independent experiments

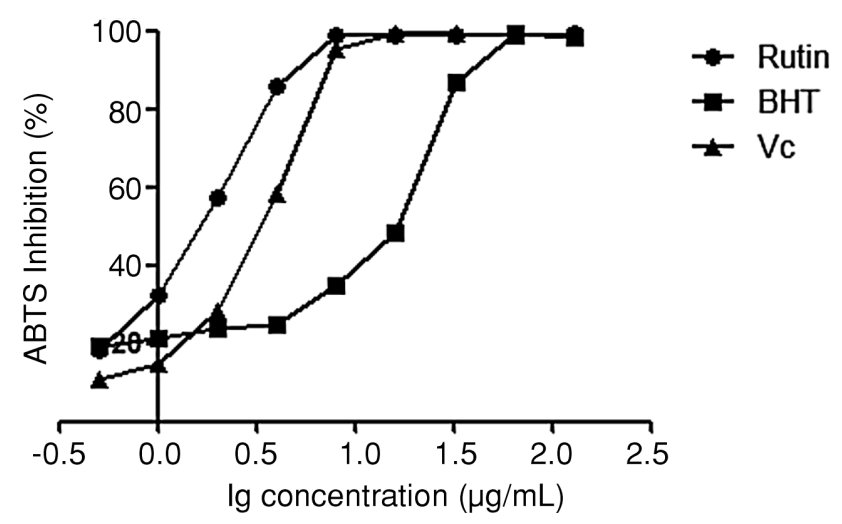

Figure 9. The assay of $\mathrm{IC}_{50}$ of rutin, $\mathrm{BHT}$ and $\mathrm{VC}$ on $\mathrm{ABTS}$ radical. Values represent the mean $\pm \mathrm{SD}$ of the three independent experiments

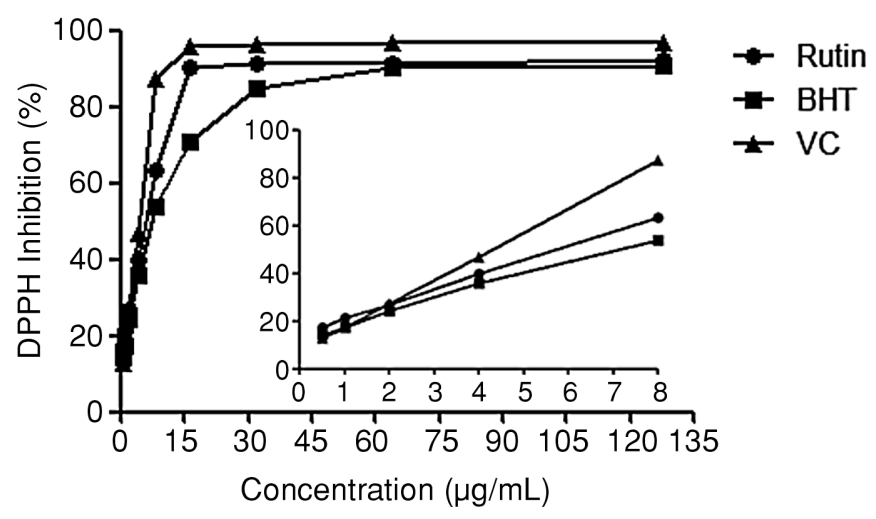

Figure 10. The scavenging activity of different concentrations of rutin, BHT and VC on DPPH radical. Values represent the mean \pm SD of the three independent experiments 


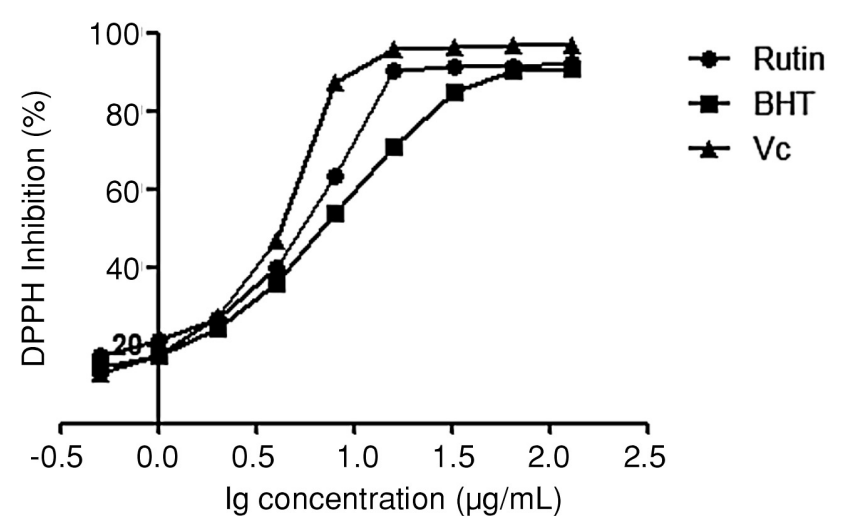

Figure 11. The assay of $\mathrm{IC}_{50}$ of rutin, BHT and $\mathrm{VC}$ on DPPH radical. Values represent the mean $\pm \mathrm{SD}$ of the three independent experiments

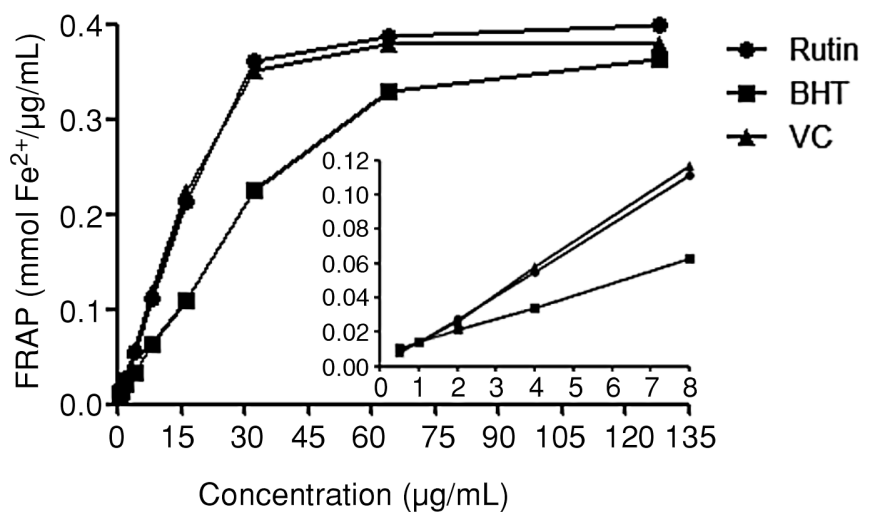

Figure 12. The reducing capacity of different concentrations of rutin, BHT and VC on the ferric ion. Values represent the mean \pm SD of the three independent experiment

icals. The results are nearly consistent with the previous reports (30), rutin exhibited strong DPPH radical scavenging activity, and at the concentration of $50 \mu \mathrm{g} / \mathrm{mL}, \mathrm{VC}$, BHT and rutin showed $92.8 \%$, $58.8 \%$, and $90.4 \%$ inhibition, respectively. DPPH free radical scavenging activity of rutin was also increased with an increasing concentration 5, 20, 30, 50 and $70 \mu \mathrm{g} / \mathrm{mL}$.

Meanwhile, FRAP of rutin, VC and BHT demonstrated the same trend as ABTS radicals scavenging activity assay. FRAP of rutin was 0.028 mmol $\mathrm{Fe}^{2+} / \mu \mathrm{g} / \mathrm{mL}$ stronger than $\mathrm{VC}$ with 0.026 $\mathrm{mmol} \mathrm{Fe}^{2+} / \mu \mathrm{g} / \mathrm{mL}$, and the lowest value for BHT with $0.021 \mathrm{mmol} \mathrm{Fe}{ }^{2+} / \mu \mathrm{g} / \mathrm{mL}$. These results suggest that rutin is a powerful free radical inhibitor or scavenger and a remarkable reducing agent to donate an electron to reactive free radicals. Therefore, rutin will be a very interesting candidate for the research and development of healthy and natural antioxidant in the food and pharmaceutical industries.

Figure 8,10 and 12 described the trend lines of interaction relation between the concentration $(0.5$, $1.02 .0,4.0,8.0,16.0,32.0,64.0,128.0 \mu \mathrm{g} / \mathrm{mL}$ ) of rutin, BHT and $\mathrm{VC}$ and their antioxidant activities. As shown in Figure 8, the scavenging ABTS free radical ability of rutin was greater than $\mathrm{VC}$ with the concentration less than $8 \mu \mathrm{g} / \mathrm{mL}$, and the scavenging ability was almost the same with the concentration more than $8 \mu \mathrm{g} / \mathrm{mL}$. Moreover, the scavenging DPPH free radical ability of VC was greater than rutin with the concentration higher than $4 \mu \mathrm{g} / \mathrm{mL}$ (Fig. 10). For FRAP assay (Fig. 12), the reducing capacity of rutin and VC were almost identical. The scavenging ABTS and DPPH radicals activities and 
FRAP of rutin and VC were stronger than BHT with the concentration from 2 to $128 \mu \mathrm{g} / \mathrm{mL}$, which suggests that rutin and vitamin $\mathrm{C}$ can be considered first when high concentration or more than $2 \mu \mathrm{g} / \mathrm{mL}$ of antioxidants are needed, which not only have better antioxidant activity, but also have less toxic side effects than BHT.

Pearson correlation analysis between rutin concentration and antioxidant activity

In this study, the antioxidant activities of rutin were investigated using the assay of ABTS radical scavenging activity, DPPH radical scavenging activity and FRAP. Meanwhile, Pearson test was utilized to analyze and evaluate the interaction between the content of rutin, BHT, VC, and their antioxidant activities. As shown in Table 2, the correlations were significant $(\mathrm{p}<0.05)$ between the concentration of rutin and the antioxidant activity measured by DPPH (r, 0.673) and FRAP (r, 0.723) assays. Furthermore, there were better correlations between the content of BHT and the values of DPPH $(r$, $0.759 ; \mathrm{p}<0.05)$ and FRAP $(r, 0.810 ; \mathrm{p}<0.01)$ assays (Table 3 ). In addition, the correlation was significant $(p<0.05)$ between the concentration of VC and the antioxidant activity measured by FRAP $(r, 0.686)$ assay (Table 4$)$. In addition, a comparison was made on the use of ABTS and FRAP methods for the measurement of the total antioxidant capacity (TAC) of plant foods and six antioxidant reference substances including rutin, and the results were recalculated to allow a comparison so that Trolox had a TAC-value of $1.00 \mu \mathrm{mol} / \mu \mathrm{mol}$ (34). These results indicated that the assay methods can be suc-

Table 2. Correlation coefficients between antioxidant activity assays and the concentration of rutin.

\begin{tabular}{|c|c|c|c|c|}
\hline & ABTS & DPPH & FRAP & Concentration of rutin $(\mu \mathrm{g} / \mathrm{mL})$ \\
\hline ABTS & 1 & $0.884^{* *}$ & $0.855^{* *}$ & 0.503 \\
\hline DPPH & - & 1 & $0.996^{* *}$ & $0.673^{*}$ \\
\hline FRAP & - & - & 1 & $0.723^{*}$ \\
\hline $\begin{array}{c}\text { Concentration of } \\
\text { rutin }(\mu \mathrm{g} / \mathrm{mL})\end{array}$ & - & - & - & 1 \\
\hline
\end{tabular}

$* *$ Significant at $\mathrm{p}<0.01 ; *$ Significant at $\mathrm{p}<0.05$

Table 3. Correlation coefficients between antioxidant activity assays and the concentration of BHT.

\begin{tabular}{|c|c|c|c|c|}
\hline & ABTS & DPPH & FRAP & Concentration of rutin $(\mu \mathrm{g} / \mathrm{mL})$ \\
\hline ABTS & 1 & $0.825^{* *}$ & $0.812^{* *}$ & 0.640 \\
\hline DPPH & - & 1 & $0.980^{* *}$ & $0.759^{*}$ \\
\hline FRAP & - & - & 1 & $0.810^{* *}$ \\
\hline $\begin{array}{c}\text { Concentration of } \\
\text { BHT }(\mu \mathrm{g} / \mathrm{mL})\end{array}$ & - & - & - & 1 \\
\hline
\end{tabular}

$* *$ Significant at $\mathrm{p}<0.01 ; *$ Significant at $\mathrm{p}<0.05$

Table 4. Correlation coefficients between antioxidant activity assays and the concentration of VC.

\begin{tabular}{|c|c|c|c|c|}
\hline & ABTS & DPPH & FRAP & Concentration of rutin $(\mu \mathrm{g} / \mathrm{mL})$ \\
\hline ABTS & 1 & $0.995^{* *}$ & $0.952^{* *}$ & 0.576 \\
\hline DPPH & - & 1 & $0.973^{* *}$ & 0.609 \\
\hline FRAP & - & - & 1 & $0.686^{*}$ \\
\hline $\begin{array}{c}\text { Concentration of } \\
\text { VC }(\mu \mathrm{g} / \mathrm{mL})\end{array}$ & - & - & - & 1 \\
\hline
\end{tabular}

$* *$ Significant at $\mathrm{p}<0.01 ; *$ Significant at $\mathrm{p}<0.05$ 
cessfully and veritably used to measure the antioxidant activity of rutin, BHT, VC. In addition, Table 2 to 4 also listed the correlation coefficients between any two of the antioxidant activities assays, which were very significant $(r>0.812 ; \mathrm{p}<0.01)$ for any two of the assay methods, and the results implied that there was better correlation for the three evaluation methods for antioxidant activity, which can be accurately and scientifically evaluate the antioxidant activity of the analytes. Even if the ABTS, DPPH and FRAP methods all showed a better performance with the samples analyzed in the present study, the use of one-dimensional method has many limitations. Therefore, the antioxidant activity of the analyte can be objectively and truly evaluated by a variety of methods, including ABTS, DPPH, FRAP and other methods.

\section{CONCLUSION}

This study evaluated the dose-effect relationship of rutin on the anti-inflammatory and antioxidant activities in vitro against LPS-stimulated RAW 264.7 cells and free radicals or ferric-ion. 5, 10, 20, 50 and $100 \mu \mathrm{M}$ of rutin were proved to be a better anti-inflammatory drug via observation cell morphological, determination of the content of NO and the levels of TNF- $\alpha$, IL- $1 \beta$ and IL- 6 , and evaluation of the phagocytic activity. In addition, it is worth mentioning that rutin exerts stronger antioxidant activities than BHT, and equivalent to $\mathrm{VC}$, which were verified by the assay ABTS, DPPH radical scavenging activity, and FRAP. Therefore, rutin might be regarded as a new, healthy and natural drug or additive associated with anti-inflammatory and antioxidant activities for pharmaceutical and food industries.

\section{Conflict of interest}

The authors have no conflict of interest to declare.

\section{Ethical approval}

This article does not contain any studies with human participants or animals performed by any of the authors.

\section{Acknowledgments}

We are grateful for the financial support from the Liaoning Province Natural Science Foundation (Grant No. 20180550647).

\section{REFERENCES}

1. Bouglé A., Bombled C., Margetis D., Lebreton G., Vidal C. et al.: PLoS One 13, e0194976 (2018).

2. Devarapu S. K., Anders H.J.: J. Biomed. Sci. 25, 35 (2018).

3. Harris T.J., Beck W.C., Bhavaraju A., Davis B., Kimbrough M.K. et al.: J. Surg. Case Rep. 3, rjy048 (2018)

4. Gomaa E.Z.: Food Sci. Biotechnol. 22, 455 (2013).

5. Sebastiano M., Eens M., Abd- Elgawad H., Thoisy B., Lacoste V. et al.: Sci. Rep. 7, 1599 (2017).

6. Lins T.L.B.G., Cavalcante A.Y.P., Santos J.M.S., Menezes V.G., Barros V.R.P. et al.: Theriogenology 89, 263 (2017).

7. Yeh C.H., Yang J.J., Yang M.L., Li Y.C., Kuane Y.H.: Free Radic. Biol. Med. 63, 249 (2014).

8. Lu J., Wang J.S., Kong L.Y.: J. Ethnopharmacol. 134, 911 (2011).

9. Girón N., Pérez-Sacau E., López-Fontal R., Amaro-Luis J.M., Hortelano S. et al.: Eur. J. Med. Chem. 45, 3155 (2010).

10. Kim B., Lee J.H., Seo M.-J., Eom S.H., Kim W.: Food Sci. Biotechnol. 25, 1437 (2016).

11. Tian C.L., Zhang P., Yang C.X., Gao X., Wang H. et al.: Mediators Inflamm. 2,1 (2018).

12. Aun M.V., Blanca M., Garro L.S., Ribeiro M.R., Kalil J. et al.: J. Allergy Clin. Immunol. Pract. 2, 414 (2014).

13. Blumenthal K.G., Lai K.H., Huang M.S., Wallace Z.S., Wickner P.G., Zhou L.: J. Allergy Clin. Immunol. Pract. 5, 737 (2017).

14. Kuruvilla M., Khan D.A.: Immunol. Allergy Clin. North Am. 35, 303 (2015).

15. Mehta D., Bhargava D.K.: Apollo Medicine 7, 251 (2010).

16. Kumar G.P., Singh S.B.: Eur. J. Appl. Sci. 3, 53 (2011).

17. Zeb A., Sadiq A., Ullah F., Ahmad S., Ayaz M.: Biol. Res. 47, 76 (2014).

18. Lu N., Ding Y., Yang Z., Gao P.Z.: Int. J. Biol. Maromol. 89, 175 (2016).

19. Chua L.S.: J. Ethnopharmacol. 150, 805 (2013).

20. Ganeshpurkar A., Saluja A.K.: Saudi Pharm. J. 25, 149 (2017).

21. Gullón B., Lú-Chau T.A., Moreira M.T., Lema J.M., Eibes G.: Trends Food Sci. Technol. 67, 220 (2017).

22. Chen W.Y., Huang Y.C., Yang M.L., Lee C.Y., Chen C.J.: Int. Immunopharmacol. 22, 409 (2014). 
23. Ma J.Q., Liu C.M., Yang W.: Chem.-Biol. Interact. 286, 26 (2018).

24. Su K.Y., Yu C.Y., Chen Y.P., Hua K.F., Chen Y.L.S.: BMC Complement. Altern. Med. 14, 21 (2014).

25. Wang S.W., Wang Y.J., Su Y.J., Zhou W.W., Yang S.G. et al.: Neurotoxicology 3, 482 (2012).

26. Bonechi C., Donati A., Tamasi G., Leone G., Consumi M. et al.: Biophys. Chem. 233, 55 (2018).

27. Silva A.B.D., Coelho P.L.C., Amparo J.A.O., Carneiro M.M.A.D.A., Borges J.M.P. et al.: Chem.-Biol. Interact. 274, 89 (2017).

28. Dubey S., Ganeshpurkar A., Ganeshpurkar A., Bansal D., Dubey N.: FJPS 3, 158 (2017).

29. Diwan V., Brown L., Gobe G.C.: J. Funct. Foods. 33, 85 (2017).

30. Yang J.X., Guo J., Yuan J.F.: LWT 41, 1060 (2008).
31. Alhoshani A.R., Hafez M.M., Husain S., Alsheikh A.M., Alotaibi M.R. et al.: BMC Nephrology 18, 194 (2017).

32. Gautam R., Singh M., Gautam S., Rawat J.K., Saraf S.A., Kaithwas G.: BMC Complement. Altern. Med. 16, 99 (2016).

33. Arts M.J.T.J., Dallinga J.S., Voss H.P., Haenen G.R.M.M., Bast A.: Food Chem. 88, 567 (2004).

34. Nilsson J., Pillai D., Őnning G., Persson C., Nilsson Å., Åkesson B.: Mol. Nutr. Food Res. 49, 239 (2005).

35. Chen Y.C., Shen S.C., Lee W.R., Hou W.C., Yang L.L., Lee T.J.F.: J. Cell. Biochem. 82, 537 (2001).

36. Saraphanchotiwitthaya A., Sripalakit P.: ScienceAsia 41, 5 (2015).

37. Yang R.F., Zhao C., Chen X., Chan S.W., Wu J.Y.: J. Funct. Foods. 17, 903 (2015).

Received: 30.10 .2018 